\title{
Strengthening 'folk ecology': community-based learning for integrated soil fertility management, western Kenya
}

\author{
Joshua J. Ramisch ${ }^{1}$, Michael T. Misiko ${ }^{2}$, Isaac E. Ekise ${ }^{3}$ and John B. Mukalama ${ }^{3}$ \\ ${ }^{1}$ University of Ottawa, International Development and Globalization, Vanier Hall, 11 Marie Curie, Ottawa, Ontario, \\ K1N 5C8; ${ }^{2}$ Technology and Agrarian Development (TAO), Wageningen University and Research-Centre (WUR), \\ Wageningen, The Netherlands; and ${ }^{3}$ TSBF-Maseno, PO Box 25199, Kisimu, Kenya
}

\begin{abstract}
Farmers and researchers in western Kenya have used community-based learning approaches to jointly develop a 'dynamic expertise' of integrated soil fertility management (ISFM). This transformative learning approach builds on farmers' 'folk ecology' and outsiders' knowledge, taking action research on natural resource management beyond methods that are descriptive (ethnopedology) or curriculumdriven (farmer field schools). The paper presents insights from a project's experience of applying the strengthening 'folk ecology' approach in western Kenya, with emphasis on the community-based learning process, collective and individual experimentation, the power dynamics of farmer research groups, and learning from the farmer-researcher interface. Farmer groups have been empowered by this approach but diversification into non-soil activities highlights the limitations of experimentation and the challenges of scaling up participatory action research.
\end{abstract}

Keywords: Local knowledge, farmer experimentation, natural resource management, soils, Africa

$\ldots$ if the field's unknown and new to us, / Before our plough breaks open the soil at all, / It's necessary to study the ways of the winds / And the changing ways of the skies, and also to know / The history of the planting in that ground, / What crops will prosper there and what will not. (Virgil, The Georgics, lines 50-53 (36-29 BC) (Ferry, 2005)

\section{Introduction}

Like farmers throughout history, African smallholders understand, manage, and respond to their environment (Brokensha et al., 1991; Sikana \& Mwambazi, 1996). Repertoires of this local knowledge are embodied as practical skills to manage livelihoods and agricultural systems, and to adapt

\footnotetext{
*Corresponding author. Email: jramisch@uottawa.ca
}

these systems to constantly changing ecological and socio-economic conditions (Richards, 1985; van Veldhuizen et al., 1997). Yet Africa's present reality - of decreasing agricultural productivity, decreasing food security and increasing rural poverty - seems to suggest that African farmers can no longer entirely depend on existing local knowledge and traditional adaptation strategies (Fairhead \& Scoones, 2005).

The failure of many decades of scientific research to raise the productivity of African farming systems has prompted agronomy and soil science to move beyond a paradigm of simple 'nutrient provision' to embrace integrated soil fertility management (ISFM). ISFM is a holistic approach to understanding and managing the full range of processes (biological, physical, chemical, social, economic and political) that influence soil fertility (TSBF, 2005). That ISFM approaches are interested in the 
knowledge of local people parallels a more general growth in interest in marginalized knowledges, which has its roots in the humbling of Westerntrained scientists after more than half a century of failed development enterprises (Kothari, 2002).

Studies of local environmental knowledge typically address the importance of local practices by understanding them either on their 'scientific' merits (e.g. Ettema, 1994; Richards, 1985; Sikana, 1993) or within their broader socio-cultural context (Amanor, 1994; Berkes, 1999; Winklerprins \& Barrera-Bassols, 2004). Research on communication between knowledge systems demonstrates how natural resource management currently neglects (but can be improved with reference to) local knowledge and skills (e.g. Berkes et al., 2003; Mazzucato \& Niemeijer, 2001; Moller et al., 2004; Oberthür et al., 2004; Röling \& van de Fliert, 1994; Sperling et al., 1993; Talawar \& Rhoades, 1998).

This paper critically reviews experiences of going beyond these two positions, applying communitybased learning and farmer-led experimentation to reduce the epistemological and communicative 'distance' between local communities and scientists. The strengthening 'folk ecology' project (SFE) is working to broaden the repertoire of soil fertility management and adaptation strategies available to smallholders in western Kenya. It consciously uses an adaptive learning process of dialogue between farmers' local ecological knowledge ('folk ecology') with outside knowledge systems to develop a shared 'dynamic expertise' of soil fertility management.

This contrasts with the structured curricula of 'farmer field school' approaches, which build farmers' understanding of science as a replacement for simply following scientific recommendations (Dilts \& Hate, 1996). The SFE model does not automatically presuppose vast differences in epistemology or 'cosmovision' between farmers and other populations (Millar, 1993), nor does it assume important synergies between different knowledge sets (Sumberg et al., 2003). However, identifying and understanding differences (and similarities) where they exist must constitute a starting point for any collaborative venture, especially given the many ways in which concepts of soil ecology might be embedded within more holistic concerns about crop performance, climate, water, pests or markets).
Such an approach could be criticized as resource intensive, time consuming, and site specific. Yet the lessons covered here present the complexity with which technology is understood, adapted, and adopted by its potential users. They also reveal the multiple ways in which 'dynamic expertise' is generated, shared ('scaled out') or withheld within community-based, social learning systems. The complexity inherent to social learning will not be avoided by retreating to purely scientistdriven technology development, suggesting that local studies like this one are fundamental to understanding the dynamics of technology adoption and use.

\section{Project and site description}

The SFE project has operated in western Kenya since 2001, led by the Tropical Soil Biology and Fertility Institute of the International Centre for Tropical Agriculture (TSBF-CIAT), supported by the African Highlands Initiative (AHI), the Kenyan Agricultural and Foresty Research Institutes (KARI, KEFRI), Ministry of Agriculture (MoA), and local non-governmental organizations (NGOs) such as the Sustainable Community Based Input Credit Scheme (SCOBICS). The project's goal is to show that local 'folk' knowledge and practice can be strengthened through repeatable, enduring processes rooted in local institutions, actors and processes that are not inherently reliant on a project's presence.

Western Kenya is an area historically neglected by central authorities; rural populations contend with poor infrastructure, poor market access, high rates of HIV/AIDS infection, and widespread, semi-permanent out-migration of youth (predominantly young men) (Crowley \& Carter, 2000). Both land and labour shortages frequently limit agriculture in western Kenya, which is also beset with many biophysical problems beyond soil fertility decline, such as significant climatic variability and widespread crop pests, weeds, and diseases.

The SFE project involves ethnically distinct communities chosen along an agro-ecological and population density gradient from Vihiga district through to Busia and Teso districts (Table 1). All four sites have some previous contact with either international or local NGOs working on soil fertility management. 
Table 1 Overview of study sites and composition of farmer research groups (2005)

\begin{tabular}{||l|c|c|c|c|c|c|}
\hline $\begin{array}{l}\text { Site name } \\
\text { (district) }\end{array}$ & $\begin{array}{c}\text { Population } \\
\text { density } \\
\text { (people } / \mathbf{k m}^{\mathbf{2}} \text { ) }\end{array}$ & $\begin{array}{c}\text { Annual } \\
\text { precipitation } \\
\text { (mm) }\end{array}$ & $\begin{array}{c}\text { Average } \\
\text { residents/ } \\
\text { household }\end{array}$ & $\begin{array}{c}\text { Average } \\
\text { farm size } \\
\text { (ha) }\end{array}$ & $\begin{array}{c}\text { Farmer } \\
\text { groups }\end{array}$ & $\begin{array}{c}\text { Participating } \\
\text { households }\end{array}$ \\
\hline Ebusiloli (Vihiga) & 1317 & $1800-2000$ & 4.5 & 0.34 & 3 & 75 \\
\hline Butula (Busia) & 462 & $1270-1790$ & 4.3 & 0.92 & 5 & 58 \\
\hline Matayos (Busia) & 359 & $1270-1790$ & 4.6 & 1.39 & 6 & 82 \\
\hline Chakol (Teso) & 436 & $760-1015$ & 5.5 & 1.85 & 2 & 48 \\
\hline
\end{tabular}

Source: Muruli et al., 1999; Republic of Kenya, 2001; authors' own data

The sites' climate is bi-modal, with rains falling in the 'long' first season (April-July) and again during the 'short' second season (October-December). Livelihoods are subsistence-based and (as elsewhere in western Kenya) maize is the dominant staple food. Other crops include beans, sweet potatoes, sugar cane, bananas, cowpeas, sorghum, millet, cassava, kale and other green vegetables, coffee, cotton (Busia), French beans and tea (Vihiga).

\section{'Folk ecology': knowledge as practice}

The potentially unfamiliar term 'folk ecology' has been intentionally retained for four reasons. First, it makes explicit the association with other bodies of 'folk' knowledge that are studied within anthropology or geography (e.g. folk medicine, folk biology) (Berlin et al., 1966). It usefully encapsulates an 'everyday' opposition to the formally structured languages of science or philosophy, largely because this knowledge works as lived metaphor rather than simply as literal statements (Bellon \& Taylor, 1993). Second, by reference to 'ecology' this environmental knowledge is shown to have a systematic and scientific basis rooted in both social ('folk') and environmental (ecosystem) contexts (Richards, 1975). Third, by choosing a label that does not emphasize 'knowledge' as a coherent body (as the term 'indigenous technical knowledge' implies) we hope to demonstrate that any knowledge ('folk' or not) is disparate, complex and potentially even contradictory (Jansen, 1998). Finally, it avoids misleading or cumbersome designations like 'local' or 'indigenous' (Agrawal, 1995). While the knowledge in question does stem from the lived experiences of rural communities, these are not 'indigenous people' as such. Indeed the research goal has been to demonstrate that knowledge generated in a given 'locality' has much to share with other knowledge systems and can constitute a basis for 'pan-local' understanding. Otherwise, 'local' risks becoming a term that de-legitimizes and devalues rural people's lived experiences as something parochial contrasted with purportedly 'universal', ahistorical scientific knowledge (Ramisch et al., forthcoming).

Local and outsiders' knowledge interact to understand, for example, what is meant by soil 'fertility'. The farmer and researcher use of similar terms can appear to bring common understanding, but 'fertility' might refer to a physical property, a chemical or biological one or the ability of a soil to produce good yields given a favourable climate or weed/pest regime (Niemeijer \& Mazzucato, 2003). Concepts such as soil 'type' are also generated by both scientists and farmers to serve a purpose by explaining the universe. Farmers' knowledge of soils tends to exhibit non-exclusive taxonomic properties (Ettema, 1994), or overlays names for landforms, history of possession, or soil characteristics in a non-hierarchical fashion and different actors to match their land management decisions to the local resources available to them (Fairhead and Scoones, 2005).

Current interest in ethnopedology and related 'ethno-sciences' has grown out of participatory research that recognized the value of rural people's knowledge for the development, evaluation, and diffusion of new agricultural technologies (Ashby et al., 1995; Bentley, 1994; Winklerprins \& Sandor, 2003). Studies of 'ethno-sciences' have identified and documented local taxonomies in many fields, including soils and productive environments (Bellon \& Taylor, 1993; Carter \& Murwira, 1995; Sandor \& Furbee, 1996), insects and pests 
(Bentley, 1994), crops and crop varieties (Richards, 1986) and soil and water management practices (Lamers \& Feil, 1995).

Soil knowledge, including that encapsulated by scientific learning, develops in cultures through long-term interactions with the environment and use of land resources (Sandor \& Furbee, 1996). Indigenous knowledge often appears quite extensive and systematic, taking into account complex local interconnections and heterogeneity that scientific knowledge may overlook in the search for generalized 'truths' (Sillitoe, 1998). Pieri et al. (1995) reported farmers' knowledge of symptoms associated with land and plant productivity, including local means of detecting leaf symptoms, and soil chemical imbalances. Based on this finding, researchers have used local knowledge as a rapid method for assessing soil fertility and crop performance without field trials (Warren, 1989). Local knowledge allows scientists to identify the soils that are important to farmers, determine each soil's relative productivity and locate typical examples of each soil (Pawluk et al., 1992). Arshad and Coen (1992) indicate that many soil attributes can be estimated by calibrating quantitative observations against measured values. Such ethnopedological research typically recommends integrating local and technical soil quality information to optimize the management of local resources and external soil inputs (Defoer et al., 1998). Nevertheless, there are still few tested ways of how to achieve this effectively.

According to Barrera-Bassols and Zinck (2000), over half of ethnopedology studies they reviewed focus on soil nomenclature and/or taxonomies. Focusing exclusively on outward attributes (e.g. a local taxonomy or characteristics of local soil types) downplays or neglects the very important domain of concepts, perceptions and beliefs, in other words, the local frame of reference of soil knowledge in which physical, economic and socio-cultural factors interact (Winklerprins \& Barrera-Bassols, 2004). Furthermore, if the role of scientific inquiry is merely to identify local practices in order to 'validate' their scientific merits or to win broader recognition for peasant wisdom or insights, it will often be the case that local systems appear only as 'simplified' versions of some more complete, universal 'reality'. Local taxonomies, for example, are not the same as the hierarchical models favoured by scientists, and the conflicts between different epistemologies are often fundamentally unresolvable (Sikana, 1993). Thus even well intentioned, 'participatory' methods risk marginalizing these local knowledges merely as 'starting points' for knowledge integration exercises (Nadasdy, 1999).

\section{Strengthening 'folk ecology': methods beyond ethnopedology}

The SFE project began with an interest in broadening the discussion of local soil agro-ecological knowledge beyond ethnopedology to see soil management within its local context. In the terminology of Niemeijer and Mazzucato (2003) identifying and using the full 'grammar' (local theories) rather than just the 'sentences' (taxonomies) of local knowledge provides a much clearer insight into how farmers will deal with changing circumstances and new crops.

The project has followed an iterative procedure of establishing (and revisiting) the norms of interaction between researchers and farmers for conducting a set of activities seen in Figure 1. The highly abstracted diagram of activities portrays the researcher-farmer interface at the heart of the generation of a 'dynamic expertise' of knowledge and skills, with iterative cycles of experimentation and reflection around new technologies. Dialogue occurs in both group and one-on-one meetings between farmers and researchers as part of both formal and informal interactions. Group and individual 'experiment' sites are important, but

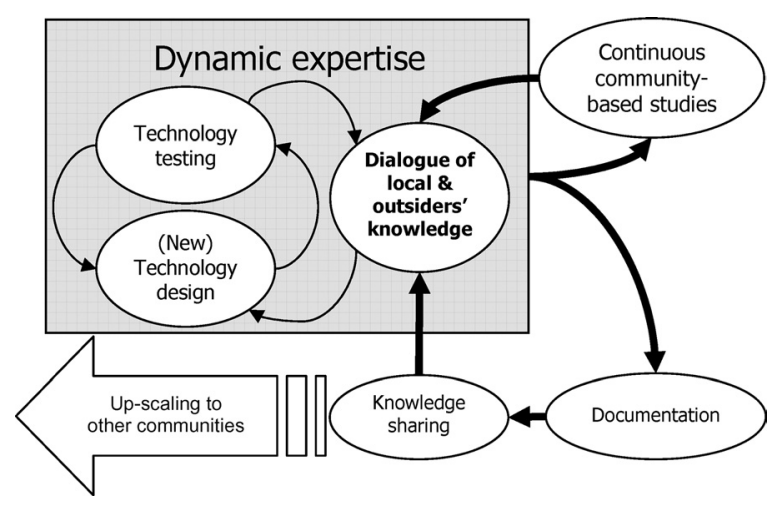

Figure 1 The strengthening 'folk ecology' approach 
encounters also include the sharing of data (collected by farmers and/or researchers), observations, and opinions about new or on-going agricultural activities. In keeping with transformative learning philosophy, the regularity of interactions through repeated seasons builds both trust and a repertoire of shared experience and observations. This experience with the process of designing, testing and selecting technologies has been studied continuously at the community level (Misiko et al., 2004). Documentation (by researchers and farmers alike) of the process and products of the on-going dialogues is critical for the knowledge sharing that feeds into the iterative generation of 'dynamic expertise'. Documentation and knowledge sharing also feed into the scaling up and ultimate sustainability of the SFE approach.

\section{The researcher-farmer (outsider-local) interface}

Although SFE is explicitly a project about soil fertility management, generating 'dynamic expertise' is an inherently political process, which confronts different versions of 'local' knowledge within a framework of differentiated resources, skills and authority (Mosse, 2002). The project has therefore always remained alert to how these differences might manifest themselves in interactions as tensions or conflicts, expressed openly or subtly.

For example, it is clear that farmers have multiple reasons to participate in a 'project' (mradi), many of which are only remotely connected to a desire to strengthen one's own 'folk ecology'. Distinguishing 'research' (utafiti) from 'development' (maendeleo) is hard enough for researchers increasingly pressed to deliver 'impact' from their studies; participating farmers usually assumed that utafiti should simply be a process of 'educated experts' demonstrating 'known facts' in the community. This grew of course from farmers' familiarity with being 'taught' passively to follow scientific recommendations under the conventional 'transfer of technology' approach (Salas, 1994). Many development NGOs in the communities also had a history of paying farmers to attend meetings ('lunch' or 'sugar'), paying for collective work or providing free inputs. These payments are today implicit in the term 'mradi', given ironic names in local vernacular like 'facilitation' or 'empowerment'. The perceived failure of SFE to pay such 'facilitation' has been a frequent source of contention between farmers and researchers, although other participants decried such expectations as 'bribing us to do our own work'.

'Scientific' knowledge is itself deeply contested, with debates between various paradigms, disciplines and epistemologies. In rural Kenya, a cyclic pattern exists whereby whatever the farmer knows or is currently practising is at least partly at odds with the dominant scientific discourse (Ramisch et al., forthcoming). For example, farmers in the 1940s were urged to adopt iron hoes and ploughs to increase their labour productivity, while today they are told that such implements cause soil erosion and therefore undermine their productivity (Crowley \& Carter, 2000). Scientific debates about the sustainability of local practices are played out in rural Kenyan communities only through intermittent contacts with continually changing 'outside' actors and their differing messages. This mutability (and farmers' sceptical response to it) is reinforced by the political manoeuvres of local NGOs, who must win adherents to their projects to demonstrate 'impact' to their donors. In so doing, these 'outside' actors use polemical presentations of how their message differs from that of 'rival' actors, extolling for example the virtues of 'organic' agriculture or agroforestry or farming based on agro-chemical inputs as the 'new', 'best' practice. The notion that an existing repertoire of soil fertility management already exists or should be built on does not enter such political equations.

\section{Lessons learned}

\section{Soil ecological knowledge is not universally held or understood}

Dialogues in multiple settings showed that the levels of 'folk ecology' knowledge ranged from a few local 'specialists' to more widespread 'core' knowledge (i.e. 'what minimum I should know about soil to manage it for my needs?'). Certain aspects of soil fertility management (i.e. compost preparation, intercropping) are well known but are used at different levels of mastery or interest. Other aspects (i.e. indicators of nutrient 
deficiencies, pest control, reading the signs of a 'good' or a 'bad' season) are much more specific to sites or individuals and may not be shared widely. The details of such knowledge are often jealously guarded or hotly contested if they come up in public debates.

Soil fertility knowledge and the decisions about how to allocate scarce resources to manage soil are deeply contextual. Many farmers look to climatic indicators to judge whether the coming rains will be favourable or not, before making any decisions about soil fertility management. Such indicators (including bird migrations, frog songs, the temperatures of water pots, or the types of tunnelling made by termites) appear to extend well outside the realm of soil fertility. However, the reasoning is that fertilizers or manure will be wasted without reliable rains.

The social and economic reasons for certain choices (i.e. to intensively 'build up' or 'exploit' given parts of the farmscape) reinforce the geomorphic and pedological processes that generate the soil fertility gradients that can be observed at the landscape level (Tittonell et al., 2005). Due to farmer interest, SFE research on this topic was concentrated on understanding the management of home gardens, which are a special component of soil fertility gradients with diverse roles in local livelihoods (particularly those of women).

Gender differences in knowledge were observed to be occasionally acute, particularly where women have married into communities far from their places of origin. Women in such situations had to rely on the experiences of other, older women with a similar history of moving but a longer residence in the new area. Women's self-help groups were particularly useful in promoting this kind of mentorship and knowledge exchange (Otwoma, 2004).

Farmer's specific knowledge of soil nutrition varied considerably and was often presented in a confusing or incomplete fashion. Despite many years of fertilizer promotion by the Kenyan government and NGO bodies, many farmers (especially, but far from exclusively, women) assumed that all mbolea ya kizungu (fertilizers: 'white man's' or inorganic 'manure') were equivalent to each other, and were unaware of the different nutrients provided by the locally available fertilizers. Many of the collective experiments therefore decided to specifically include the different inorganic inputs available (urea and diammonium phosphate (DAP)) for testing purposes. One donor visitor to the SFE research groups in late 2003 remarked that he had never before met farmers in western Kenya who could so articulately explain their soil's phosphorus deficiency and the ways it could be overcome.

The knowledge of local plant (or insect) species that could indicate soil or compost quality was also very unevenly distributed and often contested. Farmers relied heavily on their memories of site history to interpret such indicators (usually in the sense of 'improving' or 'declining' fertility), but would argue at length with each other about how to 'read' indicators in a site whose history was unknown. A species' presence or absence, its population density, and general performance are all useful guides to how a site may be changing over time, but researchers should be wary of attempting to use 'local indicators' as a shortcut towards understanding soil status in absolute terms (Mairura, 2005).

\section{Develop a shared language}

The local names of soils, landforms or processes were initially as unfamiliar to scientists (even those born in nearby communities) as the names of nutrients or fertilizers were to many farmers. Agreeing on a shared lexicon allowed project participants to show each other respect and establish tangible evidence of a common cause.

In many cases, the local communities 'rebaptized' elements of outsiders' knowledge with more accessible and expressive local names. For example, the soil nutrients nitrogen and phosphorus were given the much more pronounceable, women's names Jeni and Fosi (potassium was already known as 'kali', bitter, after a salt made from bean leaves), a popular bean variety (KK15) was named ndombolo after a popular dance, and the devastating maize stem borer renamed 'Osama'. In 2005, as the SFE project began a second phase, many groups decided to rebaptize the project itself in local idiom, such as the KiTeso phrase Keteteut Alipo ('let us renew our soils').

\section{Experiments must follow local logic}

Experimentation at collective and individual levels has been central to the SFE approach. This has 
provided tangible activities as 'sites' around which to build a common language and understanding of soil fertility and soil fertility change. These 'sites' have also allowed participants to investigate what knowledge elements constitute a 'common sense' that is widely held and understandable to a given population, rather than merely focusing on the specialist knowledge of a few experts (locals or outsiders) or key informants.

These experiments grew naturally out of groups' interests in testing and 'proving' which technologies and concepts were most appropriate to their milieu. Farmers applied their own, extensive criteria for experimental design, site selection, and evaluation. The left column of Table 2 shows the criteria applied in Ebusiloli for the first collective experiment, which tested the relative merits of different organic resources as soil inputs (guided by TSBF's Organic Resource Database criteria of nitrogen content, lignin and polyphenol contents) (Palm et al., 2001). At the same time, organic resources were combined with different treatments of inorganic $\mathrm{N}$ and $\mathrm{P}$ to allow the interactions of organic and inorganic inputs to be contrasted with those inputs used on their own.
In this first experiment, the community was relatively uncritical of the received wisdom from the research team, treating the plot as a 'demonstration' of known facts about resource quality. The relatively complex design, combining organic and inorganic resources was accepted too without hesitation, and most participants later admitted assuming that all the treatments (including unconventional inputs like the low quality maize stover) were actually 'recommendations' for soil improvement.

The experimental results differed greatly between the sites, and were also sometimes at odds with predictions. Initially some farmers expressed consternation, 'If even the scientists can't grow maize here, what hope do we have?' The design did not prove too complex for farmers to explain to each other and to visitors (to the surprise of some biophysical scientists), and the results prompted significant discussions. Discussion increased once farmers learned that what had been assumed to be a demonstration of universal 'truths' had produced different results in the different sites.

By experiencing directly that research (utafiti) is unpredictable, farmers were emboldened to

Table 2 Evolution of the 'local logic' for experiment/demonstration (Ebusiloli, 2002-2003)

\begin{tabular}{|c|c|c|}
\hline & Initial logic (2002) & Later logic $(2003+)$ \\
\hline Experimental topic(s) & $\begin{array}{l}\text { Test organic resource quality concept with } \\
\text { maize as test crop: } \\
\text { - High quality: Tithonia diversifolia } \\
\text { (abundant local shrub) } \\
\text { - Medium quality: Calliandra calothyrsus } \\
\text { (agroforestry tree) } \\
\text { - Low quality: maize stover } \\
\text { - Local practice: farmyard manure } \\
\text { Test all organic resources } \pm \text { key soil } \\
\text { nutrients }(\mathrm{P}, \mathrm{N}+\mathrm{P})\end{array}$ & $\begin{array}{l}\text { Test organic resource quality concept with } \\
\text { maize-bean intercrop } \\
\text { Test organic resource quality concept on } \\
\text { local vegetables and kales } \\
\text { Test cereal-legume rotations: } \\
\text { - Dual-purpose soybean } \\
\text { - Mucuna pruriens } \\
\text { - Local legume (cowpea, green gram, } \\
\text { yellow gram, groundnut) } \\
\text { - Local practice: maize-bean only } \\
\text { Test all options } \pm \text { inorganic } P\end{array}$ \\
\hline Experimental design & $\begin{array}{l}\text { Simple grid layout for easy comparison } \\
\text { No replication (to save on space) }\end{array}$ & $\begin{array}{l}\text { Simple grid retained } \\
\text { Farms as replicates on same soil types } \\
\text { Blanket treatments of pesticide avoided }\end{array}$ \\
\hline Site selection & $\begin{array}{l}\text { Currently fallow (low fertility) site in need } \\
\text { of restoration } \\
\text { Visible from the main road }\end{array}$ & $\begin{array}{l}\text { Low fertility sites on main local soil types } \\
\text { prioritized } \\
\text { Land size, acceptability of land owner } \\
\text { more important than 'visibility' }\end{array}$ \\
\hline Evaluation & \multicolumn{2}{|c|}{$\begin{array}{l}\text { 'Good performance' of maize was defined in terms of: uniformly dark green leaves, rate } \\
\text { and vigour of germination, rate of growth (height, size of stem, width and length of } \\
\text { leaves), uniform height of crop, presence of soil fertility indicator grasses and forbs }\end{array}$} \\
\hline
\end{tabular}


challenge the design and interpretation of the collective plot. This brought the 'local logic' of experimentation to the fore (Table 2, right column) by emphasizing relevant controls and comparisons. The researchers' use of maize as the test crop, for example, was criticized ('no-one grows maize here without beans'), as was the spraying of a pesticide against stem borer (farmers cited links between soil fertility, maize performance and stem borer infestation, and further noted that few could afford this spray anyway!). The site location, which had prioritized visibility and degraded soil but belonging to a difficult group member, was also reassessed in favour of more criteria of social acceptability and cooperation with the group's majority. Inclusion of new local groups in the following year meant that collective experiments could be replicated on similar soil types.

\section{Expect farmer experiments to diversify spontaneously}

Different experimental results, local concerns and priorities meant divergent interests for follow-up activities became apparent immediately after the conclusion of the first experiments on crop nutrition and resource quality. Coordinating research efforts so that different sites could learn from each other's experiences became quite challenging, walking a fine balance between supporting groups to test the same concepts independently in different sites and facilitating innovation in unique directions. Table 3 shows how at the group and individual level activities have continued to diversify from 2001-2006, including: the use of dual-purpose or high biomass grain legumes in rotation with the standard maize-bean intercrop, identifying and applying new high quality materials from local vegetation that would perform 'like Tithonia', improving the quality of farmyard manure (FYM) and compost through selective management of inputs and control of aeration, and applying organic resource quality concepts and inorganic fertilizers to non-cereal crops, such as market vegetables (kales) or to home garden crops.

Individual experiments have been carried out by farmers in every group and by 2005 numbered in the hundreds. While based at least in part on the collective experiments there are many divergences. Documentation of individual experiments shows three rough categories: (1) testing how a concept

Table 3 Collective and individual experiments on soil fertility management topics

\begin{tabular}{|c|c|c|c|c|c|c|}
\hline & 2001 & 2002 & 2003 & 2004 & 2005 & $2006 *$ \\
\hline $\begin{array}{l}\text { Resource quality (maize- } \\
\text { bean test crop) }\end{array}$ & C (1) & C (4) & $\begin{array}{c}\text { C (4) } \\
\text { I (30+) }\end{array}$ & & & \\
\hline $\begin{array}{l}\text { Resource quality (kale and } \\
\text { vegetable test crops) }\end{array}$ & & & I (6) & $\begin{array}{l}\text { C (4) } \\
\text { I (48) }\end{array}$ & I (5) & I (5) \\
\hline $\begin{array}{l}\text { Resource quality (addition to } \\
\text { compost) }\end{array}$ & & & I $(20+)$ & I (11) & I (12) & I (12) \\
\hline $\begin{array}{l}\text { Improved farmyard manure } \\
\text { (FYM) }\end{array}$ & & $\begin{array}{l}\text { C (2) } \\
\text { I (6) }\end{array}$ & I (35) & I (47) & I $(80+)$ & I (80+) \\
\hline Legume - cereal rotations & & & C (4) & $\begin{array}{l}\text { C (4) } \\
\text { I (?) }\end{array}$ & C (4) I (5) & $\begin{array}{l}\text { C (6) } \\
\text { I (20+) }\end{array}$ \\
\hline $\begin{array}{l}\text { Legume (soya) - cereal } \\
\text { intercropping }\end{array}$ & & & & I $(40+)$ & $I(110+)$ & I (110+) \\
\hline $\begin{array}{l}\text { Inorganic fertilizer } \\
\text { comparisons }\end{array}$ & C (1) & $\begin{array}{l}\text { C (4) } \\
\text { I }(50+)\end{array}$ & $I(50+)$ & $I(50+)$ & $I(50+)$ & $\mathrm{I}(50+)$ \\
\hline $\begin{array}{l}\text { Weed (S. hermonthica) } \\
\text { control (legumes, IR maize) }\end{array}$ & & & & & $C(3)$ I (15) & $\begin{array}{c}\text { C (6) } \\
\text { I (100+) }\end{array}$ \\
\hline
\end{tabular}

C: Collective experiment (\# farmer research groups); I: Individual experiment (\# of households).

*Planned activities. 
works, (2) seeing if it is flexible enough for other uses, and (3) making it convenient for use.

- Validating concepts. Such farmers tested a subset of the components from the collective experiment on their own farms. Usually these would be the 'most impressive' treatments (e.g. Tithonia and FYM from the resource quality experiments, or soybean varieties screened in later experiments), with the goal of seeing whether the high performance could be reproduced. This type of experiment was typically only conducted once before farmers decided whether the practice was worthwhile or not.

- Adapting concepts to new uses. Farmers observed many novelties within the process of collective experimentation (e.g. new crops, varieties, or soil inputs), which could be put to new uses. Some farmers, impressed by the high nutrient content and rapid decomposition of Tithonia, tested whether it could be added to compost piles (to 'speed the "cooking" of wastes') rather than apply it directly to the soil. New legume varieties that performed well in the legume-cereal rotations were tested as intercrops with cereals to 'save land' and time. This used existing logic of inter-planting maize and common beans (often in the same hole), but because of stronger competition effects, subsequent generations of experimentation have tried new spacing arrangements.

- Streamlining and improving practices. The most common type of experiment tinkered with practices to adapt them to individual conditions. Many farmers concluded that it was too time and capital consuming to use the experimental inputs (organic or inorganic) in large areas, such as cereal plots, and have opted instead to concentrate them on higher value crops (such as vegetables) grown on small plots. Seed availability constrains the use of the most popular new varieties of soybean and local vegetables introduced in the collective experiments. This has led other farmers to grow these crops as seed sources for their groups, while testing spacing, intercropping, and pest management.

Our empirical experience that experimentation is a normal, if not inherent, part of smallholder agriculture confirms the findings of many others (Sumberg \& Okali, 1997; van Veldhuizen et al.,
1997). But the conclusions that farmers and researchers draw from experimentation may not be equivalent. The vast majority of farmers' experiments used no replicates: treatments that performed poorly once were often rejected. In individuals' experiments, differences in performance would often be attributed as much to site history as to the effects of different treatments. Researcher-designed experiments often used up to three replicates per treatment, but frequently also had to appeal to site histories of charcoal burning or Striga infestation to explain conspicuous variation between replicates of the same treatment.

\section{Accept and work with changeable groups}

Groups and group activities have been the preferred means for engaging existing local social networks. Previous experience in the region (Misiko, 2000; Muruli et al., 1999) showed that groupbased approaches allow farmers of varying resource endowments to reduce the risks of experimentation and to benefit from shared resources (pooled labour, farm implements, manure, etc.), while also learning from one another and jointly participating in planning.

In the study communities, participants have (re)constituted either new or existing social units as 'groups' with varying degrees of formality, under labels as 'farmer field schools', 'farmer research groups', 'self-help groups', 'women's groups', or 'youth groups'. The decisions on naming and focus have been largely informed by the level of exposure to (and enthusiasm or contempt for) other agricultural development activities in the area. Typically groups have stabilized around 15-25 members. Groups that began with more members inevitably have split or seen attrition to reach this size. Although not always obvious to outsiders, relationships based on blood ancestry, marriage, gender or age have also been important in deciding who is (or is not) a potential member. While most of the groups cut across a diversity of social groups in the given communities, several groups (notably in Chakol and Butula) have reconfigured their activities to favour women-only or more homogenous, economically and culturally identified groups. This kind of rifting and restructuring of groups appears fundamental to the process of learning and empowerment, but may 
also be symptomatic of internal power struggles and other social dysfunctions.

\section{Use formal and informal means to handle elites and disruptive personalities}

A group-based approach confronts both systemic (political) and individual (personality) problems, which can paralyse activity. However, in cultures that place a high value on politeness or if there is uncertainty about how outsiders would react to dissent, even hotly contested issues might only be expressed as subtle tension or ironic comments. It is important therefore to provide a variety of channels (both formal and informal) to establish trust and communication between different participants in the project to properly address problems.

Who makes the 'best' liaison between local communities and outsiders is one such contested issue. The project team had prior experience in Ebusiloli of supporting a local extension agent to serve as 'community facilitator', a person who could mobilize farmers for meetings and experiments, facilitate trainings and local farmer-to-farmer debates, and be accessible to farmers most of the time (Woomer et al., 2003). Yet local communities saw that these tasks could be done just as easily by group members, without the introduction of an outsider with an agenda of their own. Conflicts between the facilitator, his favourites and the rest of the group became known through passive and active resistance to group activities, personality clashes and subtly satirical lyrics in songs performed for visitors. Ultimately, rival groups were set up in adjacent homes and instituted policies to select 'neutral' facilitators from amongst their own ranks.

Because most of the groups replicated local structures of authority (based on age, gender, education, or government authority) they attract local elites who either 'capture' the most lucrative activities or are quickly confirmed as the 'appropriate' leaders (Chambers, 1983). The project has tried to minimize the potential for abuse by allowing elites to feel important with formal acknowledgement but simultaneously providing multiple, alternative venues for participants to interact with each other. For example, in Luyia and Teso communities young women 'cannot' (and therefore usually do not) speak freely in front of their elders. The project research team has therefore used informal settings to get the input and feedback of such women before and after group meetings, and selected some as key informants to ensure they are represented. With time, some groups have themselves developed ways to expand their membership and invite the participation of people and networks they had previously excluded.

\section{Learn from dissent, silence and 'opting out'}

With its knowledge focus, the SFE approach must stay critically aware of silences and 'easy' answers. Researchers with distant or overly sceptical attitudes, for example, or who treat their own time as more valuable than a farmer's, are quickly rewarded with simple answers, invented data, or subtle non-cooperation. Tension is common between researchers and farmers, for example, over what constitutes an 'early' start to the day and whether participation in 'all day' activities should also be paid. At the heart of this is an issue of different perceptions of time: for the participating farmers, who rise before dawn and who normally finish farm work by noon, a meeting or group activity that starts at 10:00 am is already late in their 'day'. Yet researchers travelling to the site from their office an hour or so away might consider 10:00 am early, expressing frustration that farmers would not 'keep time' and furthermore would start asking for a lunch payment if activities stretched into the afternoon. The superficial participation and knowledge sharing that occurs when both farmers and researchers are accusing the other of not being 'hard working', can be overcome only through creating opportunities to voice the latent frustrations each actor may have (see also previous section above). Given the multiple ways in which soil fertility knowledge is embedded in local activities, researchers should avoid restricting conversations 'only to soil', or steering away from wider topics, since a great deal of rich experience might be conveyed by the examples given in 'rambling' stories on seemingly unrelated topics. Taking the time to build trust and respect therefore cannot be stressed enough.

Knowledge is generated and shared in diverse ways even within a community where rival lineages (milango in Luyia) often have deeply-held beliefs about their own superiority or entitlement to 
material benefits such as education, leadership posts, or project 'facilitation'. In the project, the new, 'dynamic expertise' on soil fertility became a resource that could be shared or withheld by competing alliances. This finding contradicts the popular opinion that collective action empowers everyone in a community and that networks can be counted on to easily disseminate 'successful' technologies after a project ends (Brokensha et al., 1991). Many participating farmers recounted how individualistic behaviour and the absence of 'traditional' practices that once united communities (rituals such as beer brewing, labour sharing, etc.) undermine collective endeavours today.

\section{Use diverse ways to understand and document 'dynamic expertise'}

The project has used a combination of approaches to study and document existing and evolving knowledge within the participating communities. Both farmers and researchers have been involved in producing and updating written materials (brochures, farmers' journals and reports), photos, calendars, and oral records (poems, dramas, songs). Farmers prefer documenting and sharing the 'results' of collective and individual experimentation (largely in written formats or farmer-to-farmer seminars), and use dramas, poems, songs, and calendars to present 'conclusions' to broader audiences. Researchers have concentrated on writing summaries of the community studies (e.g. on ethnopedology, agro-ecological concepts, indicators of change and performance, oral histories of land use and livelihoods), as well as synthesizing experimental results and lab analyses (soil and vegetative) in brochures and calendars for dissemination.

The emphasis on written materials is driven by the relatively high levels of literacy and by strong farmer interest in having preserved records of the project and its achievements. However, these are by no means 'difficult' texts: the most popular format is printing experimental results on a single sheet of double-sided A4 paper, using colour photos of at least some of the group participants and sparse text and diagrams presenting yield data and the groups' own comments and observations. Another popular format for presenting information of longer-term relevance has been wall calendars.
Since calendars have a practical and aesthetic use that ensures they will be displayed and consulted for a long time (often long past the year's end), they serve as a vehicle to feature information on the agronomic and ecological lessons gained from the group's experimentation (e.g. on managing home garden vegetables for food security).

Community-led initiatives have generated many dramas and poems relating to ISFM. These began as isolated dramas and songs to support community activities. However, as time has gone on, these have become increasingly sophisticated and an important output of the project (Munro, 1998). While the content of these can tend towards stereotype and hyperbole (the format seems to encourage extreme simplification of messages), on several occasions these communityled extension efforts have provided entry points for stimulating follow-up with more technical discussions when researchers have been present. Overall, these activities appear to be more important for building in-group morale and solidarity, while only secondarily raising interest and awareness in the broader communities.

\section{Successful learning from group activities spills over}

All of the participating farmer groups have gained substantial confidence and skill from their ISFM activities. The social capital that has formed through the course of several years of collective and individual ISFM experimentation has spilled over in several ways. First, as the numbers of interested farmers grew, and as tensions over research priorities increased, several of the farmer groups have split off from original members to pursue their own activities. Thus the numbers of participating farmers increased through a fissioning of the original group, a scaling out process that has relied on founder members looking for and recruiting new members to join them in mutually interesting activities. Second, as part of this fissioning, group activities broadened considerably beyond ISFM to now include topics as diverse as raising poultry or rabbits for market, running 'merrygo-round' investment services for members (part of Kenya's 'table banking' movement), and addressing health and nutrition, including the palliative care of people living with HIV or AIDS. 


\section{Challenges and opportunities}

Knowledge-based models of participatory research or technology development intervention emphasize building farmers' understanding of science instead of simply following scientific recommendations (Dilts \& Hate, 1996). The novel aspect of the SFE approach has been teaching scientists and other outsiders to understand and work with 'folk ecology' to jointly develop a 'dynamic expertise' for soil fertility management. Fundamental questions emerging from the lessons described above concern the further role of experimentation in building 'dynamic expertise' and the limits and opportunities for scaling up participatory approaches such as SFE.

\section{Experimentation}

While 'dialogue' has been central to the joint experimentation and learning within SFE, the project has kept an agnostic attitude towards whether 'knowledge integration' as such is itself feasible or even useful (cf. Nadasdy, 1999). On the one hand, knowledge and opinions about soil fertility management clearly differed greatly within the communities. The heated debates between farmers about indicators, or the varying ways in which married women learn the ecology of their new homes, reflect that diversity and suggest that multiple 'systems' of knowledge may coexist even within a single community (or household). The benefits of bringing complementary knowledge together included identifying relationships and patterns, comparing observations across localities, and helping farmers and outsiders solve problems.

On the other hand, our findings also show that locals and outsiders design and test experiments without major methodological differences. This suggests that while knowledge sets may be compatible and complementary, we should not expect additional, conceptual 'synergies' from farmers and researchers working together (Sumberg et al., 2003). Nevertheless, joint experimentation has created new sites of common experience and shared discovery. By linking new research questions to the emerging 'dynamic expertise', scientists are able to improve research by focusing on questions of immediate relevance to the farmer research groups (e.g. applying ISFM to under-studied home garden crops, improving composting technologies, providing wider range of multi-purpose legumes for farmer experiments, etc.).

For experimentation to remain important and useful to SFE, there must continue to be a wide range of prototype technologies for farmers to validate, adapt and refine. For the moment, the emphasis has been on ISFM but the oldest groups (barely five years old) are diversifying into activities where the researchers and other project partners have little expertise (e.g. credit, health, and nutrition, etc.). Even within the agronomic experimentation, there is an ever-increasing range of factors to manage (e.g. pest-management options, suitability of crop for climate and intercropping, product marketability, etc.). The capacity of a project team that had formed for one objective (studying the 'folk ecology' of soil) is stretched as it moves to embrace ever more objectives, and further stretched if this is to cover yet more groups and sites. If ISFM is indeed destined for a supporting rather than a dominant role in these farmer groups' activities, a soiloriented research institute or project must be ready to embrace partners equipped to undertake new roles and responsibilities (and indeed phase itself out of the experimentation process when groups are ready) (Ramisch \& Misiko, forthcoming).

\section{Scaling up}

The greatest criticism of SFE by scientists and other development practitioners has been that it is perceived as an 'anthropological', 'time-consuming' and 'complicating rather than simplifying' approach. Farmer groups are indeed experimenting with and applying ISFM concepts, but on the scale of dozens of households, not hundreds or thousands. Impacts have appeared slowly and are distributed unevenly across the social landscape.

One problem lies with the production of 'dynamic expertise' itself. To be self-sustaining, this needs actors with different but complementary knowledge, new resources, and opportunities (Sperling et al., 1993). Reducing the role of outsiders and outside knowledge as part of a phasing out process probably also diminishes the flow of new ideas, potentially stagnating the 'dynamic expertise' (Sumberg et al., 2003). Seeing the enthusiasm of farmer groups for 'experimentation' in the 
project, participating researchers hoped that farmers would then start sharing the experimentation methods behind the new, 'dynamic expertise'. Instead, most farmer-to-farmer instruction downplayed the experimentation process, focusing instead on presenting the 'solutions' that emerged from experimentation. While some of this mirrors the long-standing 'transfer of technology' approach familiar to farmers, it is also true that farmers wanted to share their 'best bet' solutions to local problems directly with their friends and relatives and thereby spare them a lengthy experimentation process.

The scaling up of the 'dynamic expertise' gained through SFE is not just about disseminating information or even the knowledge behind it, but also about institutionalizing new power and confidence to challenge existing structures and assumptions (Berkes et al., 2003; Misiko, 2000; Woodhill, 2002). The potential of groups and social networks to disseminate 'dynamic expertise' or the SFE approach is therefore fundamentally linked to inherent, complex, internal politics and not just the quality of the ideas or technologies. It has become fashionable to suggest that 'more' or 'better' quality participation can overcome such power structures (Woomer et al., 2003). However, our experience has shown that groups survived, grew in number, and diversified only in response to the availability of new knowledge, resources, and contacts with outsiders (Ramisch et al., forthcoming). This finding further reinforces the conclusion that the institutionalization of the SFE approach in local groups and project partners will take it in multiple directions, subject often to the availability of resources to support the latest topics within the groups' 'dynamic expertise'. This may appear humbling to soil scientists, but should be a healthy sign, evidence that ISFM can and will be only a subcomponent of improved livelihood strategies.

\section{References}

Agarwal, A. (1995) Dismantling the divide between indigenous and western knowledge. Development and Change 26 (3), 413-439.

Amanor, K.S. (1994) The New Frontier: Farmers' Response to Land Degradation: A West African study. London: Zed Books.
Arshad, M.A. and Coen, G.M. (1992) Characterisation of soil quality: Physical and chemical criteria. American Journal of Alternative Agriculture 7, 25-31.

Ashby, J.A., Garcia, T., Guerrero, M.P., Quiros, C.A., Roa, J.I. and Beltran, J.A. (1995) Institutionalising farmer participation in adaptive technology testing with the 'CIAL'. ODI Agricultural Research and Extension Network Paper No. 57. London: Overseas Development Institute.

Barrera-Bassols, N. and Zinck, J.A. (2000) Ethnopedology in a Worldwide Perspective: An Annotated Bibliography. (ITC Publication, Vol. 77). Enschede, The Netherlands: ITC.

Bellon, M.R. \& Taylor, J.E. (1993) 'Folk' soil taxonomy and the partial adoption on new seed varieties. Economic Development and Cultural Change 41 (4), $763-785$.

Bentley, J.W. (1994). Facts, fantasies, and failures of farmer participatory research. Agriculture and Human Values 11 (2 \& 3), 140-150.

Berkes, F. (1999). Sacred Ecology: Traditional Ecological Knowledge and Resource Management. Philadelphia, PA: Taylor and Francis Publishers.

Berkes, F., Colding, J. and Folke, C. (eds) (2003) Navigating Social-Ecological Systems: Building Resilience for Complexity and Change. Cambridge, UK: Cambridge University Press.

Berlin, B., Breedlove, D.E. and Raven, P.H. (1966). Folk taxonomies and biological classification. Science 154, 273-275.

Brokensha, D., Warren, D.M. and Werner, O. (1991) Indigenous Knowledge Systems and Development. (2nd edn). Lanham: United Press of America.

Carter, S. and Murwira, H.K. (1995) Spatial variability in soil fertility management and crop response in Mutoko Communal Area, Zimbabwe. Ambio 24 (2), 77-84.

Chambers, R. (1983) Rural Development; Putting the Last First. Harlow: Longman.

Crowley, E.L. and Carter, S.E. (2000) Agrarian change and the changing relationships between toil and soil in Maragoli, Western Kenya (1900-1994). Human Ecology 28 (3), 383-414.

Defoer, T., De Groote, H., Hilhorst, T., Kanté, S. and Budelman, A. (1998) Participatory action research and quantitative analysis for nutrient management in southern Mali: A fruitful marriage? Agriculture, Ecosystems and Environment 71, 215-228.

Dilts, D. and Hate, S. (1996) IPM farmer field schools: Changing paradigms and scaling up. Agricultural Research and Extension Network (AGREN) Paper, (\#59b, 1-4). London: Overseas Development Institute (ODI).

Ettema, C.H. (1994) Indigenous soil classifications: What is their structure and function, and how do they compare to scientific soil classifications? University of Georgia. On WWW at http://www.itc. natural/ rossiter/Docs/Misc/IntroToEthnopedology. pdf. Accessed 15 September 2005. 
Fairhead, J. and Scoones, I. (2005) Local knowledge and the social shaping of soil investments: Critical perspectives on the assessment of soil degradation in Africa. Land Use Policy 22, 33-41.

Ferry, D. (2005) The Georgics of Virgil: A Translation. New York: Farrar, Strauss, and Giroux.

Jansen, K. (1998) Political Ecology, Mountain Agriculture, and Knowledge in Honduras. Thela Latin American Series no.12 (CLACS/FLACSO). Amsterdam: Thela Publishers.

Kothari, B. (2002) Theoretical streams in marginalized peoples knowledge(s): Systems, asystems, and subaltern knowledges. Agriculture and Human Values 19 (3), 225-237.

Lamers, J.P.A. and Feil, P.R. (1995) Farmers' knowledge and management of spatial soil and crop growth variability in Niger, West Africa. Netherlands Journal of Agricultural Science 43, 375-389.

Mairura, F.S. (2005) Role of indigenous knowledge and local indicators in the management of soil quality among smallholder farmers in Chuka and Gachoka divisions, Kenya. Unpublished MSc Thesis. Kenyatta University, Environmental Resource Conservation Studies.

Mazzucato, V. and Niemeijer, D. (2001) Overestimating land degradation, underestimating farmers in the Sahel. IIED Drylands Issue Paper \#101. London: International Institute for Environment and Development.

Millar, D. (1993) Farmer experimentation and the cosmovision paradigm. In W.K. de Boef, K. Amanor and K. Wellard (eds) Cultivating Knowledge (pp. 44-50). London: IT Publications.

Misiko, M.T. (2000). The potential of community institutions in dissemination and adoption of agricultural technologies in Emuhaya, western Kenya. Unpublished MA thesis. University of Nairobi, Institute of African Studies.

Misiko, M.T., Ramisch, J.J. and Mukalama, J.B. (2004) Interactive Techniques Manual: Tools, Methods and Lessons for Integrated Soil Fertility Management Research and Dialogue Applied and Adapted Under the 'Folk Ecology' Project. Nairobi: TSBF-CIAT.

Moller, H., Berkes, P. O. Lyver, F. and Kislalioglu, M. (2004) Combining science and traditional ecological knowledge: Monitoring populations for comanagement. Ecology and Society 9 (3). On WWW at http://www.ecologyandsociety.org/vol9/iss3/art2/. Accessed 28 February 2006.

Mosse, D. (2002) 'People's knowledge', participation and patronage: Operations and representations in rural development. In B. Cooke and U. Kothari (eds) Participation: The New Tyranny? (pp. 16-35). London: Zed Books.

Munro, J. (1998) The appropriateness and effectiveness of drama as an agricultural extension tool. CIAT Network on Bean Research in Africa. Occasional Publication Series, \#26. Kampala, Uganda: CIAT.
Muruli, L.A., London, D.M., Misiko, M.T., Okusi, K., Sikana, P. and Palm, C. (1999) Strengthening Research and Development Linkages for Soil Fertility: Pathways of Agricultural Information Dissemination. Unpublished report to IDRC. Nairobi: TSBF \& Institute of African Studies.

Nadasdy, P. (1999) The politics of TEK: Power and the 'integration' of knowledge. Arctic Anthropology 36 (1), 1-18.

Niemeijer, D. and Mazzucato, V. (2003). Moving beyond indigenous soil taxonomies: Local theories of soils for sustainable development. Geoderma 111, 403-424.

Oberthür, T., Barrios, E., Cook, S., Usma, H. and Escobar, G. 2004. Increasing the relevance of scientific information in hillside environments through understanding of local soil management in a small watershed of the Colombian Andes. Soil Use and Management 20, 23-31.

Otwoma, N.T. (2004) The role of indigenous knowledge in soil fertility management among smallholders of Emuhaya. Unpublished MA Thesis. University of Nairobi, Institute of African Studies.

Palm, C.A., Gachengo, C.N., Delve, R.J., Cadisch, G. and Giller, K.E. (2001) Organic inputs for soil fertility management in tropical agroecosystems: Application of an organic resource database. Agriculture, Ecosystems and Environment 83, 27-42.

Pawluk, R.R., Sandor, J. A., and Tabor, J. A. (1992) The role of indigenous soil knowledge in agricultural development. Journal of Soil and Water Conservation 47 (4), 298-302.

Pieri, C., Dumanski, J., Hamblin, A.S. and Young, A. (1995) Land quality indicators. World Bank Discussion Paper, No. 315. Washington D.C.: World Bank.

Ramisch, J.J. and Misiko, M.T. (forthcoming) Farmers' participatory evaluation of a community-based learning process: 'Strengthening Folk Ecology' for integrated soil fertility management in Western Kenya. Paper presented to Impact Assessment Workshop, hosted by CGIAR Systemwide Program on Participatory Research and Gender Analysis. Texcoco, 19-21 October, 2005.

Ramisch, J.J., Misiko, M.T., Mairura, F.S. and Otwoma, N.T. (forthcoming). Whose land degradation counts? Contentious understandings of soil fertility management in Western Kenya. In G. Dei and N.N. Wane (eds) Indigenous Knowledge: Contentions and Transformations. Toronto: University of Toronto Press.

Republic of Kenya (2001) The 1999 Population and Housing Census. Counting our People for Development. (Vol. 1). Nairobi: Central Bureau of Statistics.

Richards, P. (1975) Alternative strategies for the African environment. 'folk ecology' as a basis for community oriented agricultural development. In P. Richards (ed.) African Environment, Problems and Perspectives. London: International African Institute, 102-114.

Richards, P. (1985) Indigenous Agricultural Revolution: Ecology and Food Production in West Africa. Boulder: Westview Press. 
Richards, P. (1986) Coping with Hunger: Hazards and Experiments in an African Rice Farming System. London: Allen and Unwin.

Röling, N. and van de Fliert., E. (1994) Transforming extension for sustainable agriculture: The case for integrated pest management in rice in Indonesia. Agriculture and Human Values 11, 96-109.

Salas, M. (1994) The technicians only believe in the science and cannot read the skies; The cultural dimension of the knowledge conflict in the Andes. In I. Scoones and J. Thompson (eds) Beyond Farmer First: Rural People's Knowledge and Agricultural Research and Extension Practice. London: IT Publications, 57-68.

Sandor, J.A. and Furbee, L. (1996) Indigenous knowledge and classification of soils in the Andes of southern Peru. Soil Science Society of America Journal 60, 1502-1512.

Sillitoe, P. (1998) The development of indigenous knowledge: A new applied anthropology. Current Anthropology 39, 223-252.

Sikana, P. (1993) Mismatched models: How farmers and scientist see soils. ILEIA Newsletter 9 (1), 15-16.

Sikana, P., Mwambazi, T. (1996) Environmental change and livelihood responses: Shifting agricultural practices in the lakes depression zone of northern Zambia. In C. Reij, I. Scoones and C. Toulmin (eds) Sustaining the Soil: Indigenous Soil and Water Conservation in Africa. London: Earthscan Publications.

Sperling, L. Loevinsohn, M.E. and Ntabornvura, B. (1993) Rethinking the farmer's role in plant breeding: Local bean experts and on-station selection in Rwanda. Experimental Agriculture 29 (4), 509-519.

Sumberg, J. and Okali, C. (1997) Farmers Experiments: Creating Local Knowledge. Boulder: Lynne Rienner.

Sumberg, J., Okali, C. and Reece, D. (2003) Agricultural research in the face of diversity, local knowledge and the participation imperative: Theoretical considerations. Agricultural Systems 76, 739-753.

Talawar, S. and Rhoades, R.E. (1998) Scientific and local classification and management of soils. Agriculture and Human Values 15 (1), 3-14.
Tittonell, P., Vanlauwe, B., Leffelaar, P.A., Shepherd, K.D. and Giller, K.E. (2005) Exploring diversity in soil fertility management of smallholder farms in western Kenya II. Within-farm variability in resource allocation, nutrient flows and soil fertility status. Agriculture, Ecosystems and Environment 110, $166-$ 184.

Tropical Soil Biology and Fertility (TSBF) (2005) Integrated Soil Fertility Management in the Tropics: From Knowledge to Implementation. CIAT Publication No. 343. Nairobi: TSBF-CIAT. On WWW at http://www.ciat.cgiar.org/tsbf_institute/index_tsbf. htm. Accessed 15 September 2005.

van Veldhuizen, L., Waters-Bayer, A., Ramírez, R., Johnson, D.A. and Thompson, J. (eds) (1997) Farmers' Research in Practice: Lessons from the Field. London: IT Publications.

Warren, D.M. (1989) Linking scientific and indigenous agricultural systems. In J.L. Compton (ed.) The Transformation of International Agricultural Research and Development. Boulder: Lynne Rienner, 153-170.

Winklerprins, A.M.G.A. and Sandor, J.A. (2003) Local soil knowledge: Insights, applications, and challenges. Geoderma 111, 165-170.

Winklerprins, A.M.G.A. and Barrera-Bassols, N. (2004) Latin American ethnopedology: A vision of its past, present, and future. Agriculture and Human Values 21, 139-156.

Woodhill, J. (2002) Sustainability, social learning and the democratic imperative: Lessons from the Australian Landcare movement. In C. Leeuwis, and R. Pyburn (eds) Wheelbarrows Full of Frogs: Social Learning in Rural Resource Management. (pp. 317-331). Assen, The Netherlands: Koninklijke Van Gorcum.

Woomer, P.L, Omare, M.N. and Mukhwana, E.J. (2003) The operations of rural self-help groups. In C.N. Savala, M.N. Omare and P.L. Woomer (eds) Organic Resource Management in Kenya: Perspectives and Guidelines. Nairobi: FORMAT. On WWW at http:// www.formatkenya.org/book\%20format.htm. Accessed 28 September 2005. 